\title{
Effects of paclobutrazol's pre-treatment on cold tolerance induction in soybean seedling (Glycine max L.)
}

\author{
Mahmood Attarzadeh, ${ }^{1}$ Hamidreza Balouchi, ${ }^{1}$ Mohammad Reza Baziar ${ }^{2}$ \\ ${ }^{1}$ Department of Agronomy and Plant Breeding, Faculty of Agriculture, Yasouj University, Yasouj; \\ ${ }^{2}$ Department of Agronomy and Plant Breeding, College of Agriculture, Fasa Branch, Islamic Azad \\ University, Fasa, Iran
}

\begin{abstract}
Paclobutrazol is one of the growth regulators in plants. It is from the Triazoles group, which can protect plants from all kinds of tension. In order to investigate the effect of cold stress and paclobutrazol on physiological characteristics of soybean seedling (cv. Williams), a factorial experiment was conducted base on completely randomised design with three replications. The first factor involved applying cold tension at $5^{\circ} \mathrm{C}$ in four intervals times $(0,8$, 16 and $24 \mathrm{~h})$. The second factor involved pre-treatment of paclobutrazol in four concentrations $(0,100,500$ and $1000 \mu \mathrm{M})$. The results showed a significant increase in shoot's dry weight by $100 \mu \mathrm{M}$ paclobutrazol application compared to non-paclobutrazol in eight hours of cold tension. The highest amount of chlorophyll $a$ and relative water content was shown by 100 and $500 \mu \mathrm{M}$ paclobutrazol application, respectively. The increase in cold tension time to $24 \mathrm{~h}$ caused an increase in ion leakage and led to an increase in protein content, catalase and peroxidase antioxidant enzymes. The results of this study demonstrate that cold tension can cause reduction in shoot's dry matter and change the physiological characteristics of soybean but application of 100 and 500 $\mu \mathrm{M}$ of paclobutrazol can partly induce tolerance to cold stress.
\end{abstract}

Correspondence: Hamidreza Balouchi, Department of Agronomy and Plant Breeding Department, Faculty of Agriculture, Yasouj University, Yasouj, Iran.

Tel.: +98.917.189.2040. E-mail: balouchi@yu.ac.ir

Key words: Cold tension; dry weight; ion leakage; peroxidase; soybean.

Acknowledgements: we thank from Fars Agricultural \& Natural Resources Research \& Education Center, Shiraz, Iran and Fasa Branch, Islamic Azad University, Fasa, Iran for technical support. We thank Meelad Ranaiefar (Texas A\&M University, College Station, Texas, USA) for their comments regarding the improving the grammar and editing and formatting the manuscript.

Received for publication: 1 June 2017.

Revision received: 23 October 2017.

Accepted for publication: 13 November 2017.

(C) Copyright M. Attarzadeh et al., 2018

Licensee PAGEPress, Italy

Italian Journal of Agronomy 2018; 13:1034

doi:10.4081/ija.2018.1034

This article is distributed under the terms of the Creative Commons Attribution Noncommercial License (by-nc 4.0) which permits any noncommercial use, distribution, and reproduction in any medium, provided the original author(s) and source are credited.

\section{Introduction}

Soybean [Glycine $\max$ (L.) Merr.] of Fabaceae family is a short day and thermophilic plant. The grain is composed of $20 \%$ oil, $36 \%$ protein, $30 \%$ carbohydrate and fiber, vitamins and minerals (Abdraimova et al., 2014). It also comprises $44 \%$ of the global share for the production of edible oil. However, production of this crop plant in Asia and Africa is 5\% of the total global amount of soybean (FAO, 2010). The trade and industry importance of soybean has led researchers to seek a greater understanding of soybean biology. In turn, this understanding could be used to enhance yield, nutritional quality and resistance to various biotic and abiotic stresses, including cold tension (Abberton et al., 2016).

Reduction of temperature in temperate climates with high elevations, especially at night, leads to the disruption of metabolism and growth of soybean and restricts its cultivation (Van Heerden et al., 2003). Exposure to low temperature above the freezing point, between zero to $5^{\circ} \mathrm{C}$, causes physiological disorders (like reduction of membrane fluidity) in the plant (Beck et al., 2004). The symptoms of cold include the reduction of growth and photosynthesis rate, ionic leakage from cell's membrane, changes in production of ethylene and respiration, and the increase in production of reactive oxygen radicals (Kuan-Hung et al., 2006; Tadjvar et al., 2011). Generally, the mechanisms of resistance to cold in plants include the changes in lipids of the membrane (to increase the fluidity of the membrane), increase the activities of antioxidants, storage of anthocyanins and change in the morphology of growth (Sariri et al., 2011). Other mechanisms of resistance include the storage of carbohydrates, pectin, nucleic acids and anti-freezing proteins, and the increase in synthesis of compounds against freezing with high or low molecular weight in the cytoplasm (Sariri et al., 2011).

Some of the researchers have reported the effects of plant growth regulators like Triazole in resistance to cold (Mahmut Sinan et al., 2009). Commercial Triazole like paclobutrazol is used as a fungicide and plant growth regulator (Fletcher et al., 2000). Most of the studies have shown that external application of paclobutrazol in tensioned plants can reduce the damaging effects of tension and restore the growth processes instantly (Khan et al., 2009). The resistance, which is produced by Triazole, is often explained by hormonal changes such as the increase in the internal content of growth regulators (e.g. cytokinin and abscisic acid) and ethylene decrease (Wilhelm et al., 1987). It is reported that the reduction in ethylene may associate with the reduction of activities in Amino-cyclopropane-carboxylic acid oxidase enzyme. Since the precursor of both ethylene and polyamine is S-adenosine methionine, ethylene biosynthesis inhibition causes an increase in polyamines, which play an important role in cold stress tolerance (Fletcher et al., 2000). Furthermore, increases in antioxidant 
enzymes activities such as superoxide dismutase, glutathione reductase, and ascorbate peroxidase are reported under the influence of Triazole (Kuan-Hung et al., 2006).

With the seasonal change from winter to early spring, cold tension in some parts of Iran can continue restricting the cultivation and growth of soybean, thus evaluation of the various approaches to solve this problem is vital. One such solution stems from several reports, which claim the positive effects of paclobutrazol as a cold tolerance inducer in different crops. Therefore the aim of this study was to evaluate the soybean physiological characteristics in relation to the effects of seeds paclobutrazol pre-treatment in cold tension condition.

\section{Materials and methods}

\section{Experimental design and experimentation}

This study was conducted as a factorial experiment based on a completely randomised design with three replications in a research greenhouse $\left(20-15^{\circ} \mathrm{C}\right.$ in $16-8 \mathrm{~h}$ day/night, RH $\left.20-40 \%\right)$. The first factor involved applying cold tension to the soybean seedling with $5^{\circ} \mathrm{C}$ temperature in four intervals of $0,8,16$ and $24 \mathrm{~h}$. The second factor involved the pre-treatment of paclobutrazol in four concentration levels $(0,100,500$, and $1000 \mu \mathrm{M})$, which was applied to seeds. The seeds of soybeans (cv. Williams) were disinfected by sodium hypochlorite $10 \%$ for $5 \mathrm{~min}$ and washed several times with distilled water. Afterward, they were soaked in the paclobutrazol solution with specified concentration at $20 \pm 1^{\circ} \mathrm{C}$ for $24 \mathrm{~h}$ in the dark (Berova et al., 2002). After pre-treating the seeds, they were washed with distilled water several times and finally, they were planted in pots at a depth of $2 \mathrm{~cm}$. After the emergence of seedlings, they were thinned to four plants in each pot. Perlite and sand were poured in pots at a 1:1 ratio. When seeds were planted, they were watered with distilled water and after emergence, watered with Hoagland solution (Table 1) (Hoagland and Arnon, 1950). The average electrical conductivity and $\mathrm{pH}$ of Hoagland

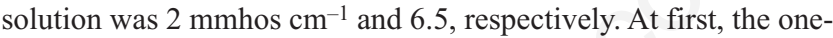
quarter strength of Hoagland solution was given to seedling and then with gradual growth of plants, half strength Hoagland was given to plants.

In order to simulate the plant growth in normal conditions, cold treatments were applied only during the night-time of plant growth. To exert the cold treatments, when the seedlings of 48 pots had four leaves, 36 pots were transferred to the growth chamber with $5^{\circ} \mathrm{C}$ temperature for $8 \mathrm{~h}$ (dark period). Then, the 36 pots that were just in the growth chamber with $5^{\circ} \mathrm{C}$ temperature were brought to the greenhouse environment to be exposed to light for a duration of $16 \mathrm{~h}$. For the second cold treatment, after the 16-h period of daylight in the greenhouse, 24 of the 36 pots were placed back in the growth chamber with a temperature of $5^{\circ} \mathrm{C}$ for $8 \mathrm{~h}$ (dark period) and then returned to the greenhouse environment for another $16 \mathrm{~h}$ of light exposure. Finally, the third cold treatment had 12 of the 24 pots undergo another cold stress stage before returning to the greenhouse environment.

\section{Parameters measured}

The dry weight was determined from shoots and roots of the soybeans after two weeks from the end of the cold treatments. Thus, the plant shoots and roots were harvested separately and washed in distilled water. Plant material was dried to a constant weight at about $70^{\circ} \mathrm{C}$ for $24 \mathrm{~h}$ and dry matter was determined. To measure the SPAD, five leaves were chosen from each pot and their greenness was read by the SPAD-502 device. Chlorophyll Fluorimeter, Hansatech LTD Pocket model, was used to measure chlorophyll fluorescence. For this purpose, the leaves were protected from the sunlight exposure by special pincers for $15 \mathrm{~min}$. After 15 min, the device's sensor was placed in the pincers and the amount of chlorophyll fluorescence was recorded by the device. The resulting number represented the photosynthetic efficiency of photosystem or $\mathrm{Fv} / \mathrm{Fm}$ (ratio of variable fluorescent to maximum fluorescent). The amount of chlorophyll $a$ and $b$ was measured by Arnon method (Arnon, 1949). The amount of light absorption of the extract prepared from the samples was read at the wavelengths of 663 and $645 \mathrm{~nm}$ by spectrophotometer (Cintra 5, Australia) and calculated from Equations 1 and 2:

Chlorophyll $a\left(\mathrm{mg} \mathrm{g}^{-1}\right)=[12.7(\mathrm{D} 663)-2.69(\mathrm{D} 645)] \times[\mathrm{V} / 1000 \times \mathrm{W}]$

Chlorophyll $b\left(\mathrm{mg} \mathrm{g}^{-1}\right)=[22.9(\mathrm{D} 645)-4.68(\mathrm{D} 663)] \times[\mathrm{V} / 1000 \times \mathrm{W}]$

where: $\mathrm{D}=$ absorption which is read in the desired wavelength; $\mathrm{W}=$ wet weight of the sample; $\mathrm{V}=$ volume of the extract.

In order to measure protein quantitatively, the Bradford method was used (Bradford, 1976) which is based on the connection of Kumasi Berliant Blue G250 to protein in the acidic environment and the determining of maximum absorption from 465 to 595 $\mathrm{nm}$. The amount of optical absorption has the direct relation with protein concentration. To measure a leaf's relative water content, Weatherely (1950) method was used. To measure the amount of ion leakage (membrane stability) the Sairam et al. (2009) method was used. In accordance to this method, two sample groups were used. In each group, $0.1 \mathrm{~g}$ of fresh and healthy tissue from the leaves was put into $10 \mathrm{~mm}$ of twice-distilled water. Test tubes of the first group were placed in a $40^{\circ} \mathrm{C}$ hot water bath for $30 \mathrm{~min}$. Then, the electrical conductivity of the sample was measured and indicated by $\mathrm{C}_{1}$. The second group was placed in a $100^{\circ} \mathrm{C}$ hot water bath for $10 \mathrm{~min}$, with the corresponding electrical conductivity indicated by $\mathrm{C}_{2}$. The membrane stability index was calculated based on Equation 3.

Membrane stability index $=\left[1-\left(\mathrm{C}_{1} / \mathrm{C}_{2}\right)\right] \times 100$

The measurement of catalase activity by Aebi method (Aebi, 1984) and Peroxidase by Mac-Adam method (Mac-Adam et al., 1992) was carried out with $0.1 \mathrm{~g}$ of fresh leaves samples.

Table 1. The composition of nutrient in Hoagland solution.

\begin{tabular}{lc} 
Nutrients & Concentration $\left(\mathrm{g} 100 \mathrm{~L}^{-1}\right)$ \\
Macronutrients & \\
$\mathrm{Ca}\left(\mathrm{NO}_{3}\right)_{2}$ & 118.10 \\
$\mathrm{KNO}_{3}$ & 50.55 \\
$\mathrm{NH}_{4}\left({ }_{3} \mathrm{PO}_{4}\right)$ & 13.61 \\
$\mathrm{MgSO}_{4}$ & 49.30 \\
$\mathrm{Micronutrients}_{\mathrm{H}_{3} \mathrm{BO}_{3}}$ & \\
$\mathrm{MnCl}_{2}$ & 2.86 \\
$\mathrm{ZnSO}_{4}$ & 2.81 \\
$\mathrm{CuSO}_{4}$ & 0.22 \\
$\mathrm{H}_{3} \mathrm{MoO}_{4}$ & 0.08 \\
$\mathrm{FeSO}_{4}$ & 0.03 \\
& 3.00 \\
\hline
\end{tabular}




\section{Statistical analysis}

The statistical analysis of data resulting from the experiment conducted by Proc GLM of SAS software and comparing means carried out by Duncan's multiple range tests at 5\% probability level.

\section{Results and discussion}

The results obtained from variance analysis related to the dry weight of soybean show that the pre-treatment of paclobutrazol, cold tension and interactions between them were significant on soybean's shoot, but they did not have any significant effect on root's dry weight (Table 2).

Effect of paclobutrazol pre-treatment, cold tension and their interaction on the relative amount of chlorophyll (SPAD), chlorophyll fluorescence parameter $(\mathrm{Fv} / \mathrm{Fm})$, content of chlorophyll $a$, soluble protein, relative water content, ion leakage, catalase and peroxidase antioxidant enzymes of soybean leaves were significant (Tables 2 and 3).

\section{Root and shoot's dry weight}

The results in controlled test (without cold tension) indicate that the maximum dry weight of soybean's shoot was in nonpaclobutrazol treatment with an average of $1.64 \mathrm{~g}$ and the lowest value obtained from the application of $100-\mu \mathrm{M}$ paclobutrazol with an average of $0.85 \mathrm{~g}$ (Table 4). In non-cold tension treatment, the application of different levels of paclobutrazol did not have significant differences on soybeans shoot dry weight, but these levels of paclobutrazol had significant differences with the non-paclobutrazol application treatment. The dry weight of shoot in $100 \mu \mathrm{M}$ paclobutrazol applications was $1.03 \mathrm{~g}$ under $8 \mathrm{~h}$ of cold tension which had a significant increase compared to $1000 \mu \mathrm{M}$ of paclobutrazol $(0.55 \mathrm{~g})$. However, it did not have a significant difference with $500 \mu \mathrm{M}$ of paclobutrazol and the control group (1.006 and $0.89 \mathrm{~g}$, respectively) (Table 5). Furthermore, in 16 and $24 \mathrm{~h}$ of cold tension, there was no significant difference between the different levels of paclobutrazol and also with zero paclobutrazol (Table 4).

The results of this study showed that the negative effect of cold became more intense with an increase in the time duration, which subsequently led to the decrease in production of shoot's dry matter. The results obtained from Table 3 also concluded that, for different cold tension durations, application of 100 and $500 \mu \mathrm{M}$ paclobutrazol could somehow increase the tolerance of soybean to cold tension. This is reflected in the increase of shoot's dry weight in these two treatments. In contrast, an application of an increasing level of paclobutrazol, up to $1000 \mu \mathrm{M}$ concentration, had an opposite effect on shoot dry matter of soybean.

The results indicated that there was a significant negative correlation between protein content, electrolyte leakage, catalase, and peroxidase antioxidant enzymes with the dry weight of soybean shoots (Table 5). The indices of chlorophyll and relative water content of the leaves had a significant and positive relationship with the dry weight of shoot. An increase in the chlorophyll in plant leads to an increase in the photosynthesis active rate and an increased production of photosynthesis matters which causes the increase in the soybean shoot's dry weight.

The decrease in the plant's growth is due to a reduction in photosynthesis and lack of carbohydrates. As a result, this can be considered as compromising response of the plant (Amooaghaie and Shariat, 2015). In cold tension conditions, instead of using carbohydrates for cell growth, plants will keep them in cells as a solute in order to decrease the freezing point of the protoplasm and avoid early cold damage (Beck et al., 2004). On the other hand, it seems that pretreatment of paclobutrazol will increase cell's division and increase cell's dry weight due to increase in chlorophyll and cytokine content (Abdul Jaleel and Kishorekumar, 2007). Jafari et al. (2006) reported that growth indices in Catharanthus roseus will be reduced in cold tension conditions, but Triazole treatment will improve this condition. This suggests that paclobutrazol probably prepares the cell to meet and overcome stress by stabilising membranes and forming a potentially of higher antioxidant capacity (Berova et al., 2002).

Table 2. Analysis of variance (mean squares) for effect of cold stress and paclobutrazol on the shoot and root dry weight, SPAD, Fv/Fm and chlorophyll $a$ and $b$ of soybean.

\begin{tabular}{lccccccc} 
S.0.V & DF & Shoot dry weight & Root dry weight & SPAD & Fv/Fm & Chl $a$ \\
Cold stress & 3 & $0.78^{* *}$ & $0.003^{\text {ns }}$ & $17.60^{* *}$ & $0.0250^{* *}$ & $0.02^{* *}$ & $0.0009^{* *}$ \\
Paclobutrazol & 3 & $0.09^{*}$ & $0.003^{\text {ns }}$ & $17.60^{* *}$ & $0.0060^{* *}$ & $0.007^{* *}$ & $0.0004^{\text {ns }}$ \\
\hline Cold stress $\times$ paclobutrazol & 9 & $0.16^{* *}$ & $0.001 n^{\text {ns }}$ & $2.50^{* *}$ & $0.0010^{*}$ & $0.004^{* *}$ & $0.0009^{* *}$ \\
Error & 32 & 0.03 & 0.002 & 0.93 & 0.0006 & 0.0006 & 0.0002 \\
\hline CV $(\%)$ & - & 21 & 8.4 & 4 & 4.5 & 7 \\
\hline
\end{tabular}

ns,${ }^{* *}$, not significant and significant at $5 \%$ and $1 \%$ probability levels, respectively.

Table 3. Analysis of variance (mean square) for effect of cold stress and paclobutrazol on leaf soluble protein, RWC, ion leakage and catalase and peroxidase of soybean.

\begin{tabular}{lcccccc} 
S.0.V & DF & Leaf soluble proteint & RWC & Ion leakage & Catalase & Peroxidase \\
Cold stress & 3 & $75.29^{* *}$ & $377.7^{* *}$ & $451.7^{* *}$ & $0.295^{* *}$ & $29.30^{* *}$ \\
Paclobutrazol & 3 & $41.12^{* *}$ & $254.8^{* *}$ & $395.9^{* *}$ & $0.044^{* *}$ & $1.12^{* *}$ \\
\hline Cold stress $\times$ paclobutrazol & 9 & $10.27^{* *}$ & $117.9^{* *}$ & $107.6^{* *}$ & $0.011^{* *}$ & $6.32^{* *}$ \\
Error & 32 & 3.11 & 6.8 & 7.9 & 0.003 & 0.17 \\
\hline CV $(\%)$ & - & 10 & 6 & 9.2 & 10 \\
\hline$* *$
\end{tabular}

${ }^{*},{ }^{* *}$, not significant and significant at $5 \%$ and $1 \%$ probability levels, respectively 


\section{Relative amount of chlorophyll}

The relative amount of chlorophyll in soybean in none, 8 and $24 \mathrm{~h}$ cold-tension conditions decreased significantly with $1000 \mu \mathrm{M}$ paclobutrazol as compared to other concentration of paclobutrazol (Table 4). In $16 \mathrm{~h}$ of cold tension, the highest relative amount of chlorophyll was reported in $100-\mu \mathrm{M}$ paclobutrazol and the lowest was observed in $1000 \mu \mathrm{M}$ concentration of paclobutrazol.

The results of this study indicated that a relative amount of soybean chlorophyll had a significant and positive relationship with the chlorophyll of leaves and dry weight of shoot indices. However, there was a significant and negative correlation with protein contents, ion leakage, catalase and peroxidase antioxidant enzymes (Table 5). The amount of chlorophyll in the leaves may indicate their resistance to cold (Aghaee et al., 2011). Cold tension will cause a decrease of chlorophyll synthesis by disturbing the enzymes' processes in the plants (Yi et al., 2015). The increase in the amount of chlorophyll in pre-treated plants is likely related to the delay in decomposition of chlorophyll and decrease in chlorophyllase activities (Fletcher et al., 2000).

\section{The maximum quantum efficiency of photosystem II photochemistry}

The Fv/Fm ratio in leaves of soybean decreased in $8 \mathrm{~h}$ tension and $1000 \mu \mathrm{M}$ paclobutrazol significantly as compared to other concentrations of paclobutrazol (Table 4). $16 \mathrm{~h}$ of cold tension with $100 \mu \mathrm{M}$ paclobutrazol exhibited a $0.72 \mathrm{Fv} / \mathrm{Fm}$ ratio, which was a significant increase compared to 500 and $1000 \mu \mathrm{M}$ paclobutrazol (0.67 and 0.65), but it did not have any significant differences when compared to control group.

By increasing the cold duration, the negative effects of cold became more intense which led to the decrease of the Fv/Fm ratio. The results of this study indicated that the Fv/Fm ratio had a negative and significant correlation with protein content, ion leakage, catalase, and peroxidase antioxidant enzymes (Table 5). Furthermore, the Fv/Fm ratio indicated a positive and significant relation with chlorophyll indices and the relative water content of the leaves (Table 5).

The flow of electrons in the photosystem is a general indicator for the overall amount of photosynthesis, and measurement of chlorophyll fluorescence makes it possible to estimate the photo-

Table 4. Effect of cold stress and paclobutrazol on shoot dry weight, SPAD, Fv/Fm and chlorophyll $a$ and $b$ of soybean.

\begin{tabular}{|c|c|c|c|c|c|c|}
\hline $\begin{array}{l}\text { Cold stress duration } \\
\text { (h) }\end{array}$ & $\begin{array}{l}\text { Paclobutrazol } \\
(\mu \mathrm{M})\end{array}$ & $\begin{array}{l}\text { Shoot dry } \\
\text { weight (g) }\end{array}$ & SPAD & $\mathrm{Fv} / \mathrm{Fm}$ & $\begin{array}{c}\text { Chl } a \\
\text { (mg/g leaf fresh weight) }\end{array}$ & $\begin{array}{c}\text { Chl b } \\
\text { (mg/g leaf fresh weight) }\end{array}$ \\
\hline Control & $\begin{array}{c}\text { Zero } \\
100 \\
500 \\
1000\end{array}$ & $\begin{array}{c}1.64^{\mathrm{a}} \\
0.85^{\mathrm{bcde}} \\
1.10^{\mathrm{b}} \\
0.88^{\mathrm{bcd}}\end{array}$ & $\begin{array}{l}25.16^{\mathrm{a}} \\
25.16^{\mathrm{a}} \\
25.16^{\mathrm{a}} \\
24.00^{\mathrm{b}}\end{array}$ & $\begin{array}{l}0.74^{\mathrm{a}} \\
0.76^{\mathrm{a}} \\
0.73^{\mathrm{ab}} \\
0.72^{\mathrm{ab}}\end{array}$ & $\begin{array}{l}0.42^{\mathrm{a}} \\
0.40^{\mathrm{a}} \\
0.41^{\mathrm{a}} \\
0.39^{\mathrm{ab}}\end{array}$ & $\begin{array}{c}0.16^{\mathrm{a}} \\
0.14^{\mathrm{abc}} \\
0.13^{\mathrm{abc}} \\
0.14^{\mathrm{abc}}\end{array}$ \\
\hline 8 & $\begin{array}{c}\text { Zero } \\
100 \\
500 \\
1000\end{array}$ & $\begin{array}{c}0.89^{\mathrm{bc}} \\
1.03^{\mathrm{b}} \\
1.00^{\mathrm{b}} \\
0.55^{\mathrm{def}}\end{array}$ & $\begin{array}{l}23.43^{b c} \\
23.43^{b c} \\
23.33^{b c} \\
21.53^{d}\end{array}$ & $\begin{array}{l}0.73^{\mathrm{ab}} \\
0.73^{\mathrm{ab}} \\
0.72^{\mathrm{ab}} \\
0.63^{\mathrm{ed}}\end{array}$ & $\begin{array}{c}0.35^{\mathrm{bc}} \\
0.40^{\mathrm{a}} \\
0.38^{\mathrm{ab}} \\
0.30^{\mathrm{d}}\end{array}$ & $\begin{array}{l}0.14^{\mathrm{abc}} \\
0.13^{\mathrm{bcd}} \\
0.14^{\mathrm{abc}} \\
0.13^{\mathrm{bcd}}\end{array}$ \\
\hline 16 & $\begin{array}{c}\text { Zero } \\
100 \\
500 \\
1000\end{array}$ & $\begin{array}{c}0.66^{\text {cdef }} \\
0.77^{\text {bcdef }} \\
0.92^{\text {bc }} \\
0.88^{\text {bcd }}\end{array}$ & $\begin{array}{c}22.63^{\mathrm{c}} \\
22.70^{\mathrm{c}} \\
22.00^{\mathrm{cd}} \\
21.53^{\mathrm{d}}\end{array}$ & $\begin{array}{c}0.69^{\mathrm{bc}} \\
0.72^{\mathrm{ab}} \\
0.67^{\mathrm{cd}} \\
0.65^{\text {cde }}\end{array}$ & $\begin{array}{c}0.32^{\mathrm{cd}} \\
0.40^{\mathrm{a}} \\
0.39^{\mathrm{ab}} \\
0.31^{\mathrm{cd}}\end{array}$ & $\begin{array}{l}0.12^{\mathrm{cd}} \\
0.14^{\mathrm{abc}} \\
0.13^{\mathrm{bcd}} \\
0.14^{\mathrm{abc}}\end{array}$ \\
\hline 24 & $\begin{array}{c}\text { Zero } \\
100 \\
500 \\
1000\end{array}$ & $\begin{array}{c}0.49^{f} \\
0.49^{f} \\
0.52^{e f} \\
0.49^{f}\end{array}$ & $\begin{array}{c}23.33^{\mathrm{bc}} \\
22.70^{\mathrm{c}} \\
23.26^{\mathrm{bc}} \\
18.63^{\mathrm{e}}\end{array}$ & $\begin{array}{c}0.61^{\mathrm{e}} \\
0.63^{\mathrm{de}} \\
0.65^{\text {cde }} \\
0.62^{\mathrm{e}}\end{array}$ & $\begin{array}{c}0.22^{\mathrm{e}} \\
0.32^{\mathrm{cd}} \\
0.35^{\mathrm{bcd}} \\
0.30^{\mathrm{d}}\end{array}$ & $\begin{array}{c}0.09^{\mathrm{e}} \\
0.15^{\mathrm{ab}} \\
0.14^{\mathrm{abc}} \\
0.10^{\mathrm{ed}}\end{array}$ \\
\hline
\end{tabular}

a-f Means followed by the same letters in each column are not significantly different by Duncan's multiple range tests at 5\% probability level.

Table 5. The correlation between Shoot dry weight, SPAD, Fv/Fm, chlorophyll a and b, Soluble protein, RWC, ion leakage, catalase and peroxidase of soybean.

\begin{tabular}{|c|c|c|c|c|c|c|c|c|c|c|}
\hline Traits & Shoot dry weight & SPAD & $\mathrm{Fv} / \mathrm{Fm}$ & Chl $a$ & Chl $b$ & Soluble protein & RWC & Ion leakage & Catalase & Peroxidase \\
\hline Shoot dry weight & 1 & & & & & & & & & \\
\hline SPAD & $0.46^{* *}$ & 1 & & & & & & & & \\
\hline $\mathrm{Fv} / \mathrm{Fm}$ & $0.48^{* *}$ & $0.60^{* *}$ & 1 & & & & & & & \\
\hline Chl $a$ & $0.51^{* *}$ & $0.52^{* *}$ & $0.71^{* *}$ & 1 & & & & & & \\
\hline Chl $b$ & $0.32 *$ & $0.35^{* *}$ & $0.37^{* *}$ & $0.53^{* *}$ & 1 & & & & & \\
\hline Soluble protein & $-0.45^{* *}$ & $-0.51^{* *}$ & $-0.41^{* *}$ & $-0.13^{\mathrm{ns}}$ & $-0.12^{\mathrm{ns}}$ & 1 & & & & \\
\hline RWC & $0.50 * *$ & $0.12^{\mathrm{ns}}$ & $0.36 * *$ & $0.47 * *$ & $0.23^{\mathrm{ns}}$ & $0.03^{\mathrm{ns}}$ & 1 & & & \\
\hline Ion leakage & $-0.44 * *$ & $-0.37 * *$ & $-0.42 * *$ & $-0.64^{* *}$ & $-0.51^{* *}$ & $-0.03^{\text {ns }}$ & $-0.74^{* *}$ & 1 & & \\
\hline Catalase & $-0.47^{* *}$ & $-0.44^{* *}$ & $-0.56 * *$ & $-0.31^{*}$ & $-0.17^{\mathrm{ns}}$ & $0.78^{* *}$ & $-0.19^{\mathrm{ns}}$ & $0.21^{\mathrm{ns}}$ & 1 & \\
\hline Peroxidase & $-0.60 * *$ & $-0.62 * *$ & $-0.67 * *$ & $-0.53^{* *}$ & $-0.32 *$ & $0.69^{* *}$ & $-0.31^{*}$ & $0.43^{* *}$ & $0.82^{* *}$ & 1 \\
\hline
\end{tabular}

ns, * ${ }^{* *}$, not significant and significant at $5 \%$ and $1 \%$ probability levels, respectively. 
synthesis. In fact, checking the state of photosynthesis is an acceptable criterion for evaluation of plant's compatibility with the environment. When stress was implemented to the plant, Fv (variable fluorescence) decreased. The result of this decrease is the destruction of the chlorophyll structure a corresponding decrease in the Fv/Fm ratio decreases (Maxwell and Johanson, 2000). The results from the researchers' studies showed that by increasing the cold tension, the Maximum quantum efficiency of PSII photochemistry in dark-adapted leave $(\mathrm{Fv} / \mathrm{Fm})$ which represented the electron transferring in the second photosystem decreased in the vegetative stage. Thus, the main reason for the decline of $\mathrm{Fv} / \mathrm{Fm}$ is the disruption in chlorophyll's state (He et al., 2015).

\section{Content of chlorophyll $a$ and $b$}

The content of chlorophyll $a$ in $100 \mu \mathrm{M}$ paclobutrazol pretreatment was $0.040 \mathrm{mg} \mathrm{g}^{-1}$, which had a significant increase compared to $1000 \mu \mathrm{M}$ paclobutrazol and the control in 8 and $16 \mathrm{~h}$ cold tension conditions. However, it did not have a significant difference with $500 \mu \mathrm{M}$ of paclobutrazol pretreatment (Table 4). In $24 \mathrm{~h}$ of cold tension, the content of chlorophyll $a$ was $0.35 \mathrm{mg} \mathrm{g}^{-1}$ with 500 $\mu \mathrm{M}$ paclobutrazol pretreatment, which had a significant increase compared to control group $\left(0.22 \mathrm{mg} \mathrm{g}^{-1}\right)$. However, it did not have a significant difference compared to 100 and $1000 \mu \mathrm{M}$ paclobutrazol pretreatment (Table 4). The content of chlorophyll $a$ had a negative and significant correlation with protein content, ion leakage, peroxidase, and catalase antioxidant enzymes (Table 5), but had a significant and positive correlation with chlorophyll indices and relative water content.

The content of chlorophyll $b$ was $0.15 \mathrm{mg} \mathrm{g}^{-1}$ with $100 \mu \mathrm{M}$ paclobutrazol, which had a significant increase compared to control and $1000-\mu \mathrm{M}$ paclobutrazol $\left(0.10\right.$ and $\left.0.09 \mathrm{mg} \mathrm{g}^{-1}\right)$ in $24 \mathrm{~h}$ tension. However, it did not have significant difference compared to $500-\mu \mathrm{M}$ paclobutrazol application $\left(0.14 \mathrm{mg} \mathrm{g}^{-1}\right)$ (Table 4$)$. The negative effect of cold became more intense with increasing duration and eventually it decreased the content of chlorophyll $b$ in soybean. The content of chlorophyll $b$ had a negative and significant correlation with ion leakage and peroxidase antioxidant enzyme, but it showed a significant and positive correlation with chlorophyll indices (Table 5).
According to the results of this study, it can be stated that the average value of chlorophyll $a$ and $b$ has decreased, under cold tension, compared to the control group. Chlorosis of the leaves, due to a decrease in the number of photosynthetic pigments, is the first symptom of cold. The decrease in the number of pigments can occur due to the effect of cold in an increased peroxidation. This damage can occur in the membrane of Chloroplasts and Thylakoids and decrease the number of pigments (Tadjvar et al., 2011). On the other hand, it seems that 100 and $500-\mu \mathrm{M}$ paclobutrazol pre-treatment can somehow have a positive effect on chlorophyll's structure and can be used as a suitable strategy to increase the content of chlorophyll under cold tension. It is reported that Triazoles can directly affect biosynthesis of isoprenoids through the impact on chlorophyll biosynthesis (Fletcher et al., 2000). The research shows that priming of bean seeds with 25 and $50 \mathrm{~g} \mathrm{~L}^{-1}$ paclobutrazol can prevent damage and protect the structures of chlorophylls as compared to untreated seedling in cold tension condition (Amooaghaie and Shariat, 2015). According to Fletcher et al. (2000), inhibition of lipid peroxidation may be one of the mechanisms responsible for the antisenescence effects of the Triazoles.

\section{Leaf soluble proteins}

The content of soluble proteins $21.83 \mu \mathrm{g} \mathrm{mg}$ leaf fresh weights $^{-1}$ in $500 \mu \mathrm{M}$ paclobutrazol and $8 \mathrm{~h}$ of cold tension had a significant increase compared to the $100 \mu \mathrm{M}$ paclobutrazol and control (17.06 and $\left.18.33 \mu \mathrm{g} \mathrm{mg}^{-1}\right)$. However, it did not have a significant difference compared to $1000 \mu \mathrm{M}$ paclobutrazol $(21.53 \mu \mathrm{g}$ $\mathrm{mg}^{-1}$ ) (Table 6).

The largest of the leaf soluble proteins content, $24.33 \mu \mathrm{g} \mathrm{mg}^{-1}$, was from $16 \mathrm{~h}$ of cold tension and $1000 \mu \mathrm{M}$ paclobutrazol, while the lowest leaf soluble proteins content, $16.43 \mu \mathrm{g} \mathrm{mg}^{-1}$, was from the control group (without paclobutrazol). In $24 \mathrm{~h}$ of cold tension, the soluble proteins content in $1000 \mu \mathrm{M}$ paclobutrazol had significantly increased compared to $100 \mu \mathrm{M}$ paclobutrazol. By increasing cold tension and paclobutrazol level, the soluble proteins content increased. This lead to the most soluble proteins being observed in $24 \mathrm{~h}$ cold tension and $1000 \mu \mathrm{M}$ paclobutrazol pretreatment (Table 6). The content of leaf soluble proteins had a positive and significant

Table 6. Effect of cold stress and paclobutrazol on average of leaf soluble protein, RWC, ion leakage and catalase and peroxidase in the leaves of soybean.

\begin{tabular}{|c|c|c|c|c|c|c|}
\hline $\begin{array}{l}\text { Cold stress } \\
\text { duration(h) }\end{array}$ & $\begin{array}{l}\text { Paclobutrazol } \\
(\mu \mathrm{M})\end{array}$ & $\begin{array}{l}\text { Soluble proteins } \\
\left(\mu \mathrm{g} \mathrm{mg}^{-1}\right)\end{array}$ & $\begin{array}{l}\text { RWC } \\
(\%)\end{array}$ & $\begin{array}{l}\text { Ion leakage } \\
(\%)\end{array}$ & $\begin{array}{c}\text { Catalase } \\
\left(\mu \mathrm{mol} \mathrm{min}^{-1} \mathrm{mg} \text { protein }{ }^{-1}\right)\end{array}$ & $\begin{array}{c}\text { Peroxidase } \\
\left(\mu \mathrm{mol} \mathrm{\textrm {min } ^ { - 1 } \mathrm { mg } \text { protein }}{ }^{-1}\right)\end{array}$ \\
\hline Control & $\begin{array}{c}\text { Zero } \\
100 \\
500 \\
1000\end{array}$ & $\begin{array}{l}16.06^{\mathrm{e}} \\
16.66^{\mathrm{de}} \\
17.66^{\mathrm{de}} \\
16.03^{\mathrm{e}}\end{array}$ & $\begin{array}{l}86^{\mathrm{ab}} \\
80^{\mathrm{cd}} \\
80^{\mathrm{cd}} \\
78^{\mathrm{cd}}\end{array}$ & $\begin{array}{l}24.30^{\text {def }} \\
23.97^{\text {def }} \\
24.33^{\text {def }} \\
23.00^{\text {ef }}\end{array}$ & $\begin{array}{l}0.40^{\mathrm{f}} \\
0.41^{\mathrm{ef}} \\
0.42^{\mathrm{ef}} \\
0.43^{\mathrm{ef}}\end{array}$ & $\begin{array}{l}4.46^{\mathrm{i}} \\
4.30^{\mathrm{i}} \\
4.48^{\mathrm{i}} \\
4.33^{\mathrm{i}}\end{array}$ \\
\hline 8 & $\begin{array}{c}\text { Zero } \\
100 \\
500 \\
1000\end{array}$ & $\begin{array}{l}17.06^{\mathrm{de}} \\
18.33^{\mathrm{de}} \\
21.83^{\mathrm{bc}} \\
21.53^{\mathrm{bc}}\end{array}$ & $\begin{array}{l}71^{\mathrm{e}} \\
80^{\mathrm{cd}} \\
87^{\mathrm{a}} \\
77^{\mathrm{d}}\end{array}$ & $\begin{array}{c}33.44^{\mathrm{c}} \\
27.33^{\mathrm{de}} \\
24.00^{\mathrm{def}} \\
24.73^{\mathrm{def}}\end{array}$ & $\begin{array}{l}0.47^{\mathrm{ef}} \\
0.48^{\mathrm{ef}} \\
0.52^{\mathrm{de}} \\
0.51^{\mathrm{def}}\end{array}$ & $\begin{array}{l}5.68^{\mathrm{h}} \\
6.49^{\mathrm{gf}} \\
6.81^{\mathrm{efg}} \\
6.22^{\mathrm{hg}}\end{array}$ \\
\hline 16 & $\begin{array}{c}\text { Zero } \\
100 \\
500 \\
1000\end{array}$ & $\begin{array}{l}16.43^{\mathrm{de}} \\
19.66^{\mathrm{cd}} \\
22.00^{\mathrm{bc}} \\
24.33^{\mathrm{ab}}\end{array}$ & $\begin{array}{l}68^{\mathrm{e}} \\
75^{\mathrm{d}} \\
82^{\mathrm{bc}} \\
80^{\mathrm{cd}}\end{array}$ & $\begin{array}{l}45.73^{\mathrm{b}} \\
35.61^{\mathrm{c}} \\
21.80^{\mathrm{f}} \\
28.66^{\mathrm{d}}\end{array}$ & $\begin{array}{l}0.52^{\mathrm{de}} \\
0.76^{\mathrm{ab}} \\
0.80^{\mathrm{ab}} \\
0.71^{\mathrm{bc}}\end{array}$ & $\begin{array}{l}7.31^{\text {cde }} \\
7.02^{\mathrm{def}} \\
7.84^{\mathrm{bc}} \\
7.70^{\mathrm{bcd}}\end{array}$ \\
\hline 24 & $\begin{array}{c}\text { Zero } \\
100 \\
500 \\
1000\end{array}$ & $\begin{array}{c}16.55^{\mathrm{de}} \\
18.00^{\mathrm{de}} \\
22.26^{\mathrm{abc}} \\
25.33^{\mathrm{a}}\end{array}$ & $\begin{array}{c}58^{\mathrm{f}} \\
61^{\mathrm{f}} \\
78^{\mathrm{cd}} \\
76^{\mathrm{d}}\end{array}$ & $\begin{array}{c}51.07^{\mathrm{a}} \\
37.94^{\mathrm{c}} \\
24.63^{\mathrm{def}} \\
37.64^{\mathrm{c}}\end{array}$ & $\begin{array}{c}0.62^{\mathrm{dc}} \\
0.71^{\mathrm{bc}} \\
0.84^{\mathrm{a}} \\
0.79^{\mathrm{ab}}\end{array}$ & $\begin{array}{l}7.37^{\text {cde }} \\
7.40^{\text {cde }} \\
8.59^{\mathrm{a}} \\
8.21^{\mathrm{ab}}\end{array}$ \\
\hline
\end{tabular}

a-i Means followed by the same letters in each column are not significantly different by Duncan's multiple range tests at $5 \%$ probability level. 
correlation with catalase and peroxidase enzymes (Table 5).

The results of this study showed that the use of paclobutrazol with increasing cold tension increased the soluble proteins of soybean leaves. The initial response to cold tension, which mainly depends on time, is induced by changes in content and activities of proteins, often dependent on the rate of temperature changes and intensities. Therefore, the intensity and duration of tension are considered as key factors in cold tension tolerance (Weber and Marahiel, 2003). Thus, cold tension will increase the storage of soluble and apoplastic proteins (Zeinali Yadeghari et al., 2008). Also, it is reported that paclobutrazol treatment significantly increased soluble proteins in common beans (Hegazi and ElShraiy, 2007).

\section{Relative water content of the leaf}

In the non-tension condition and non-paclobutrazol pretreatment, relative water content was $86 \%$ and increased significantly as compare to other levels of paclobutrazol (Table 6). The highest relative water content in the leaves $87 \%$ was from $8 \mathrm{~h}$ in tension and $500 \mu \mathrm{M}$ Paclobutrazol. The lowest relative water content, $0.71 \%$, was in control group and there was no significant statistical relationship with the application of 100 and $1000 \mu \mathrm{M}$ paclobutrazol in this condition. In 16 and $18 \mathrm{~h}$ cold tension and $500 \mu \mathrm{M}$ paclobutrazol, the relative water content had significantly increased compared to $100 \mu \mathrm{M}$ paclobutrazol, but it did not have a significant increase compared to $1000 \mu \mathrm{M}$ paclobutrazol (Table 6). The results of this study showed that relative water content in the leaves had a significant and negative relation to ion leakage and peroxidase antioxidant enzymes (Table 5).

The negative effect of cold became increasingly intense with increasing duration, and this lead to a decrease of relative water content, but the different levels of paclobutrazol pretreatment could somehow increase it. It seems that the destruction of the membrane structure and ion leakage are determinants for the decrease of the relative water content, where cold tension prevents soybean from absorbing of water. Increase in cold tension causes changes in organelles such as chloroplast and vacuole, which increases leakage of the membrane, and result in a decrease of relative water content in the leaf (Khodakovskaya et al., 2005). At the same time, with the plant's exposure to cold tension, it confronts with water tension, which begins with the hydraulic conductivity of roots and continues with a drastic decline of water potential and leaf inflammation (Joshi et al., 2007).

\section{Ion leakage}

The ion leakage of the leaf, $24 \%$, in $8 \mathrm{~h}$ cold tension condition and $500 \mu \mathrm{M}$ paclobutrazol had significantly decreased compared to control group, $33.44 \%$, but there was no significant difference with 100 and $1000 \mu \mathrm{M}$ paclobutrazol, 27.33 and $24.73 \%$, respectively. In $16 \mathrm{~h}$ of cold tension, the lowest amount of ion leakage, $21.80 \%$, was by $500-\mu \mathrm{M}$ paclobutrazol pretreatment and the highest amount of leakage, $45.73 \%$, was in control group (Table 6). The ion leakage in $24 \mathrm{~h}$ cold tension condition had significantly decreased for $500-\mu \mathrm{M}$ paclobutrazol as compared to zero, 100 and $1000 \mu \mathrm{M}$ paclobutrazol concentration (Table 6). The results of this study showed that soybean's ion leakage had a significant and positive relation with peroxidase antioxidant enzyme (Table 5).

According to the correlation coefficients, it seems that an increase in cold tension and ion leakage is a factor, which increases the peroxidase antioxidant enzymes activities. The results of this study showed that an increase in cold tension led to leakage of the cytoplasmic matters of the soybean's leaves, but pretreatment of paclobutrazol could somehow stabilise the membrane and decrease cytoplasmic leakage of the soybean leaf. Cold tension produces active oxygen species, which increase lipid peroxidation and ion leakage by attacking the membrane (Sevillano et al., 2009). In contrast, Triazoles decrease biosynthesis of cholesterol, change the composition of cholesterol in the membrane, and induce the compatibility allow for tension (Khan et al., 2009). By increasing the activities of antioxidant enzymes, Triazoles decrease the production of active oxygen species and protect the membrane (Kuan Hung et al., 2006). The studies reported that cold tension increased ion leakage of the bean membrane. In contrast, with paclobutrazol preventing ion leakage and oxidation from damaging the membrane, the harmful effects of cold tension are decreased (Amooaghaie and Shariat, 2015).

\section{Catalase and peroxidase enzymes}

The $16 \mathrm{~h}$ of cold tension condition and $500 \mu \mathrm{M}$ paclobutrazol pretreatment significantly increased the catalase enzyme's activity to $0.80 \mu \mathrm{mol} \mathrm{min}-1 \mathrm{mg}$ protein ${ }^{-1}$, compared to the control group, 0.52 $\mu \mathrm{mol} \mathrm{\textrm {min } ^ { - 1 } \mathrm { mg } \text { protein }}{ }^{-1}$, but there was no significant difference between 100 and $1000 \mu \mathrm{M}$ paclobutrazol application (Table 6). In 24 $\mathrm{h}$ cold tension, the highest amount of catalase enzyme activity was observed by $500 \mu \mathrm{M}$ paclobutrazol pre-treatment, with an average of $0.84 \mu \mathrm{mol} \mathrm{min}-1 \mathrm{mg}$ protein ${ }^{-1}$, and the lowest was seen in the control group, $0.62 \mu \mathrm{mol} \mathrm{min}{ }^{-1} \mathrm{mg}$ protein ${ }^{-1}$. By increasing the duration of cold tension in soybean, catalase enzyme activity increased significantly compared to the control group (Table 6).

The peroxidase enzyme's activity in $8 \mathrm{~h}$ cold tension with 500 $\mu \mathrm{M}$ Paclobutrazol, $6.81 \mu \mathrm{mol} \mathrm{min}^{-1} \mathrm{mg}_{\text {protein }}{ }^{-1}$, had significantly increased compared to the control group $\left(5.68 \mu \mathrm{mol} \mathrm{min}{ }^{-1} \mathrm{mg}\right.$ protein $\left.^{-1}\right)$, but there was no significant difference with 100 and 1000 $\mu \mathrm{M}$ paclobutrazol, 6.49 and $6.22 \mu \mathrm{mol} \mathrm{\textrm {min } ^ { - 1 } \mathrm { mg } \text { protein }}{ }^{-1}$ respectively (Table 6). In $16 \mathrm{~h}$ of cold tension, the maximum amount of peroxidase enzyme was shown in $500 \mu \mathrm{M}$ paclobutrazol pretreatment, 7.84- $\mu \mathrm{mol} \mathrm{min} \mathrm{mg}^{-1} \mathrm{mg}$ protein ${ }^{-1}$, and the lowest amount was observed in $100 \mu \mathrm{M}$ paclobutrazol, $7.02 \mu \mathrm{mol} \mathrm{m^{-1 }} \mathrm{mg}$ protein ${ }^{-1}$. The peroxidase enzyme activity in 500 and $1000 \mu \mathrm{M}$ paclobutrazol application had a significant increase compared to $100-\mu \mathrm{M}$ paclobutrazol in $24 \mathrm{~h}$ of cold tension condition (Table 6).

The peroxidase enzyme's activity in $8 \mathrm{~h}$ cold tension with 500 $\mu \mathrm{M}$ paclobutrazol, $6.81 \mu \mathrm{mol} \mathrm{\textrm {min } ^ { - 1 } \mathrm { mg } \text { protein }}{ }^{-1}$, had significantly increased compared to the control group $\left(5.68 \mu \mathrm{mol} \mathrm{min}^{-1} \mathrm{mg}\right.$ protein $\left.^{-1}\right)$, but there was no significant difference with 100 and 1000 $\mu \mathrm{M}$ paclobutrazol, 6.49 and $6.22 \mu \mathrm{mol} \mathrm{\textrm {min } ^ { - 1 } \mathrm { mg } \text { protein }}{ }^{-1}$ respectively (Table 6). In $16 \mathrm{~h}$ of cold tension, the maximum amount of peroxidase enzyme was shown in $500 \mu \mathrm{M}$ paclobutrazol pretreatment, $7.84-\mu \mathrm{mol} \mathrm{min}^{-1} \mathrm{mg}$ protein ${ }^{-1}$, and the lowest amount was observed in $100 \mu \mathrm{M}$ paclobutrazol, $7.02 \mu \mathrm{mol} \mathrm{m^{-1 }} \mathrm{mg}$ protein ${ }^{-1}$. The peroxidase enzyme activity in 500 and $1000 \mu \mathrm{M}$ paclobutrazol application had a significant increase compared to $100-\mu \mathrm{M}$ paclobutrazol in $24 \mathrm{~h}$ of cold tension condition (Table 6).

The results of this study showed that an increase in duration of cold tension in soybean caused a significant increase in peroxidase enzyme activity compared to the control group. In cold tension condition, high activities of antioxidant enzymes decrease oxidative tension indices, lipid peroxidation and hydrogen peroxide in the leaf cell (Apostolova et al., 2008). Any factor that increases antioxidant enzymes activities and soluble protein can play a leading role increasing the plant's cold tension tolerance (Pireivatlou et al., 2010). The result of this study showed that using paclobutrazol and increasing cold tension increases the activities of catalase and peroxidase enzymes in soybean. The activities of antioxidants in treated wheat seedlings, under cold tension, increased with 
paclobutrazol; these enzymes could decrease the production of active oxygen (Berova et al., 2002). Wanaei et al. (2012) reported that temperature decrease in the ILC428 cultivar of pea increased catalase enzymes activities and was followed by decomposition of active oxygen species.

\section{Conclusions}

The results show that cold tension has adverse effects on the stability of soybean membrane, chlorophyll indices, relative water content and the dry weight of shoots. Furthermore, it seems that pretreatment of paclobutrazol by 100 and $500 \mu \mathrm{M}$ concentrations increase catalase and peroxidase antioxidant enzymes and soluble proteins in the leaves of soybean. This defensive mechanism of soybean can be regarded as an important factor in increasing a crop's tolerance to cold tension. The capacity and ability of the antioxidant to act under cold tension conditions depends on the tolerance of the plants. This is because the activities of antioxidant enzymes in plants represent their tolerance to different tensions.

\section{References}

Abberton M, Batley J, Bentley A, Bryant J, Cai H, 2016. Global agricultural intensification during climate change: a role for genomics. Plant Biotechnol. J. 14:1095-8.

Abdraimova NA, Umbetov AK, Yeleshev RE, Goos RJ, 2014. Effect of mineral and organic fertilizers on the Soybean (Glycine max) yield and fertility of the irrigated soils. Life Sci. J. 11:256-61.

Abdul Jaleel C, Kishorekumar A, 2007. Alterations in carbohydrate metabolism and enhancement in tuber production in white yam under triadimefon and hexaconazol applications. J. Plant Growth Regul. 53:7-16.

Aebi H, 1984. Catalase in vitro. Methods. Enzymol. 105:121-6.

Aghaee A, Moradi F, Zare-Maivan H, Zarinkamar F, Pour Irandoost $\mathrm{H}$, Sharifi $\mathrm{P}, 2011$. Physiological responses of two rice (Oryza sativa L.) genotypes to chilling stress at seedling stage. Afr. J. Biotechnol. 10:7617-21.

Amooaghaie R, Shariat E, 2015. Effect of cultivar, cold and paclobutrazol on growth, chlorophyll content and cell membrane injury in Phaseolus vulgaris plantlet. Iran. J. Plant Biol. 6:77-90.

Apostolova P, Yordanova R, Popoval L, 2008. Response of antioxidative defense system to low temperature stress in two wheat cultivars. Gen. Appl. Plant Physiol. 34:281-94.

Arnon DI, 1949. Copper enzymes in isolated chloroplasts, polyphenoxidase in Beta vulgaris. Plant Physiol. 24:1-15.

Beck E, Heim R, Hansen J, 2004. Plant resistance to cold stress: Mechanisms and environmental signals triggering frost hardening and dehardening. Biomed. Life Sci. 9:449-59.

Berova M, Zlatev Z, Stoeva N, 2002. Effect of paclobutrazol on wheat seedling under low temperature stress. Bulgar. J. Plant Physiol. 28:75-84.

Bradford MM, 1976. A rapid and sensitive method for the quantification of microgram quantities of protein utilising the principle of protein-dye binding. Anal. Biochem. 72:248-54.

FAO, 2010. Available from: http://www.FAO.org

Fletcher R, Gilley A, Davis T, Sankhla N, 2000. Triazoles as plant growth regulators and stress protectants. Hort. Rev. 24:55-138.
He X, Sambe MAN, Zhuo C, Tu Q, Guo Z, 2015. A temperature induced lipocalin gene from Medicago falcata (MfTIL1) confers tolerance to cold and oxidative stress. Plant Mol. Biol. 87:645-54.

Hegazi AM, El-Shraiy AM, 2007. Impact of salicylic acid and paclobutrazol exogenous application on the growth, yield and nodule formation of common bean. Aust. J. Basic. Appl. Sci. $1: 834-40$

Hoagland DR, Arnon DS, 1950. The water culture method for growing plants without soil. Calif. Agricult. Exper. Stat. Exten. 374:1-32

Jafari SR, Manuchehri Kalantari KH, Turkzadeh M, 2006. The evaluation of paclobutrazol effects on increase cold hardiness in tomato seedlings (Lycopersicom esculentum L.). Iran. J. Biol. 19:290-8.

Joshi SC, Chandra S, Palni LMS, 2007. Differences in photosynthetic characteristics and accumulation of osmo-protectants in saplings of evergreen plants grown inside and outside a glasshouse during the winter season. Photosyn. 45:594-600.

Khan MSH, Wagatsuma T, Akhter A, Taukraya K, 2009. Sterol biosynthesis inhibition by paclobutrazol induced greater Aluminum sensitivity in Al-tolerant rice. Am. J. Plant Physiol. 4:89-99.

Khodakovskaya M, McAvoy R, Peters J, Wu H, Li Y, 2005. Enhanced cold tolerance in transgenic tobacco expressing a chloroplast-3 fatty acid desaturase gene under the control of a cold-inducible promoter. Planta. 223:1090-100

Kuan-Hung L, Fu-Hsiang P, Shih-Ying H, Hsiao-Feng L, 2006. Pre-treating paclobutrazol enhanced chilling tolerance of sweet potato. J. Plant Growth Regul. 49:249-62.

Mac-Adam JW, Nelson CJ, Sharp RE, 1992. Peroxidase activity in the leaf elongation zone of tall fescue I. spatial distribution of ionically bound peroxidase activity in genotypes differing in length of the elongation zone. Plant Physiol. 99:872-8.

Mahmut Sinan T, Rahmi D, Guleray A, 2009. Determination of effects of some plant growth regulators (PGRs) on changes of some isoenzymes in bean (Phaseolus vulgaris L. cv Terzibaba) at chilling temperatures: in gel enzyme assays. Rom. Biotechnol. Lett. 14:4858-69.

Maxwell K, Johanson GN, 2000. Chlorophyll fluorescence a practical guide. J. Exp. Bot. 51:659-68.

Pireivatlou AS, Dehdar Masjedlou B, Ramiz TA, 2010. Evaluation of yield potential and stress adaptive trait in wheat genotypes under post anthesis drought stress conditions. Afr. J. Agricult. Res. 5:2829-36.

Sairam RK, Dharmar K, Chinnusamy V, Meena RC, 2009. Water logging-induced increase in sugar mobilisation, fermentation, and related gene expression in the roots of mug bean (Vigna radiata). J. Plant Physiol. 6:602-16.

Sariri R, Galvani M, Fotouhi Ghazvini R, Jafarian V, 2011. The effect of cold temperature stress on antifreeze protein production and lipid peroxidation in two citrus species. Iran. J. Plant Biol. 3:97-102.

Sevillano LAT, Sanchez-Ballesta MA, Romojaro FE, Bflores FR, 2009. Physiological, hormonal and molecular mechanisms regulating chilling injury in horticultural species. Post harvest technologies applied to reduce its impact. J. Sci. Food. Agricult. 89:555-73.

Tadjvar Y, Fotouhi Ghazvini R, Hamidoghli Y, Hassan Sajedi R, 2011. Physiological and biochemical responses of page mandarin on citrange rootstock to low temperature stress. Iran. J. Plant Biol. 3:1-12.

Van Heerden PDR, Tsimilli-Michael M, Kruger GHJ, Strasser RJ, 
2003. Dark chilling effects on soybean genotypes during vegetative development: parallel studies of $\mathrm{CO}_{2}$ assimilation, chlorophyll a fluorescence kinetics O-J-I-P and nitrogen fixation. Physiol Plant. 117:476-91.

Wanaei S, Siosemardeh A, Haidari GH, 2012. The effects of cold stress at germination and seedling stages on antioxidant enzymes and some physiological aspects of chickpea (Cicer arientinum). Iran. J. Field Crops Res. 9:514-24.

Weatherely PE, 1950. Studies in water relation on cotton plants, the field measurement of water deficit in leaves. New Phytol. 49:81-7.

Weber MH, Marahiel MA, 2003. Bacterial cold shock responses. Sci. Progress. 86:9-75
Wilhelm RA, Hansjoerg FR, Jan EG, Hubert SA, Johannes JU, 1987. Tetcyclacis and triazole-type plant growth retardants: their influence on the biosynthesis of gibberellins and other metabolic processes. Soc. Chem. Ind. 21:241-52.

Yi JH, Li Y, Dai ZM, Jia ZH, Pu WX, Sun ZJ, Wang YF, Shen H, 2015. Enhanced tolerance to low temperature in tobacco (Nicotiana tabacum L.) sprayed with a low-temperature-resistant agent. Exp. Agricult. 51:179-90.

Zeinali Yadeghari L, Heidari R, Carapetian J, 2008. The influence of cold acclimation on proline, malondialdehyde (mda), total protein and pigments contents in soybean (Glycine max) seedlings. Res. J. Biol. Sci. 3:74-9. 